\title{
Design as a Factor in the Development of a Country's Economy
}

\author{
Gasimova Elfana Nasimi ${ }^{1}$, Salehzadeh Gulchohra Saleh ${ }^{2} \&$ Sugra Ingilab Humbatova ${ }^{3,4}$ \\ ${ }^{1} \mathrm{PhD}$ in Philosophy, Associate professor at Department of Design, Azerbaijan State University of Economics (UNEC), \\ Baku, Azerbaijan \\ ${ }^{2}$ The teacher at Department of Design, Azerbaijan State University of Economics (UNEC), Baku, Azerbaijan \\ ${ }^{3} \mathrm{PhD}$ in Econ., Associate professor at Department of Economy and Management, International Center for Graduate \\ Education, Azerbaijan State University of Economics (UNEC), Baku, Azerbaijan \\ ${ }^{4}$ Department of World Economy, Baku Engineering University, Khirdalan, Baku, Azerbaijan \\ Correspondence: Sugra Ingilab Humbatova, PhD in Econ., Associate professor at Department of Economy and \\ Management, International Center for Graduate Education, Azerbaijan State University of Economics (UNEC), Baku, \\ Azerbaijan. E-mail: sugra_humbatova@unec.edu.az
}

Received: July 9, 2020

doi:10.5430/rwe.v12n1p82
Accepted: November 10, 2020

Online Published: January 3, 2021

URL: https://doi.org/10.5430/rwe.v12n1p82

\begin{abstract}
Economic development is a priority in the management of any state. The article attempts to consider the impact of design on the economic condition of the country. Additionally, the connection of the country's economy, the development of design and its support from the state is analyzed. Design as a factor in the development of the country's economy is a single system, which implies a whole thread of events. In modern society, in the conditions of the paramount importance of technology in the life of every person, more than ever, it becomes important to have things convenient and practical in use. Today, the design is a strategic tool, the correct use of which leads to success in business. The relevance of the study is caused by a very low level of research on the development aspect of the country's economy - design.
\end{abstract}

Keywords: design, the economics of design, Azerbaijan, globalization, economic development factors

\section{Introduction}

Design is a type of entrepreneurial practice in the production of products with great consumer, aesthetic, moral and functional requirements, respectively design is an organization of the environment of human life that is ergonomic for a person.

In the last quarter of the 20th century, many important events of global significance took place in the world, which in Azerbaijan, unfortunately, are not always adequately understood and perceived. One of them is the consolidation of highly developed countries in the process of globalization, the basis of which is not traditional military power, but economic, legal, civilizational power. The emphasis on military confrontation and rivalry has been replaced by a focus on economic rivalry based on market mechanisms, on competition, and scientific and technological progress. At the same time, the role of nation-states as such is declining, and the role of regional economic groups and globalization as a whole is growing. Azerbaijan through the global oil and gas and communication projects is already included in this process. But its economic potential, the level of development of market infrastructure, internal competition and competitiveness do not yet meet modern requirements and standards. Therefore, we must rather complete the system transformation in order to be on a par with highly developed countries in terms of economic development, level of development of productive forces, technological level of production, and living standards of the population (Kuliev, 2007).

In these conditions, it is very important to note the political will and wisdom of the President of Azerbaijan I.G. Aliyev in the implementation of socio-economic policies aimed at developing the national economy and improving the welfare of citizens. It seems to us necessary to quote the following quotation from President I.G. Aliyeva most succinctly and succinctly characterizes the economic situation in the country and tasks in this area: "One of the main sectors of our economy is the energy, oil and gas sector. Over the past ten years, millions of dollars have been invested in it. Oil produced in the fields of Azerbaijan is today supplied to world markets through a modern pipeline 
system. The volume of oil production is growing, the revenues from it allow us to diversify our economy. Today, one of the main tasks of the government is to turn oil capital into human capital. At the same time, priority is given to the creation of new sectors of the economy, and, in particular, to ensuring industrial development. All this is done in order not to depend on oil prices in the future and have a diversified economy ... Our economic opportunities and potential are an important means not only to improve people's lives but also to strengthen the country's independence. Therefore, political development, regional cooperation, economic reforms, great attention to solving social problems is the main, priority issues for us." (Dirchialish - XX1 Yasr, 2006).

The Constitution of the Republic of Azerbaijan qualifies the country's economic system as a socially-oriented economy based on market relations (Article 15.2). The concept of a socially-oriented market economy has a wide circulation and means that the economic system is based on self-regulatory market mechanisms, and the state, in order to protect the population from excessive material inequality and other negative consequences of market imperfection, is pursuing an active social policy aimed at increasing public welfare and fair, as it considers, the distribution of income (Muzaffarli, 2014).

Semantically, the definition of "socially oriented" means "aimed at solving social problems", "working for society". Using this definition, the term "market economy" ultimately means that the economy functions not for itself or for any social group, but for the whole society, in the name of the welfare of all citizens, that all members can take advantage of the benefits created by its society (Maeda, 2008). Both theoretically and practically, the problem is complicated by the fact that in reality all states and, regardless of the professed political and economic ideology, all political groups declare their ultimate goal to be the growth of social welfare. Simply, according to one of the two dominant political and economic doctrines in the world, the shortest and most correct way to achieve this goal lies through active state regulation, and in another way through self-regulation of the economy. Naturally, there are deep differences between the ways in which these two doctrines interpret socio-economic justice. Adherents of the second believe that market self-regulation is the shortest and most effective way to achieve equitable social well-being. Given this postulate, they can argue (and argue) that a free, liberal market economy is precisely the most socially oriented economy. After that, all concepts lose their original meaning, or rather, generally lose their meaning, i.e. the need for their existence disappears (Kislitsina, 2015).

Design is an important component of the economic system, and therefore affects the standard of living of the population. The design is distinguished by its focus on innovation, the development of new trends, modern technologies and unusual materials, the quality of the consumed product and the technical properties of the created assortment, which is produced for customers with various well-being and interests (Nixson, 2001). Design is formed more rapidly than society begins to comprehend and understand the importance of the created. Design is constantly one step ahead. What society initially recognizes as absurd, unnecessary, unnatural, after a certain period of time becomes habitual. Due to the work of designers, we can imagine and see the future, for example, the image of visualizations. The development of design engineering has a direct relationship with industrial development. Design is an important segment in the development and development and advertising of any product. At the same time, the design is an important component of each company, it is a kind of "face" of the company, which allows it to become recognizable. Moreover, the industrial design includes all types of existing design elements: consumer goods, promotion, private and public interiors, production and machinery, space and military equipment, a variety of small and industrial objects, as well as the design of socially important objects.

\section{Literature Review}

The creative economy is made up of creative industries - the media, cinematography, music, entertainment software for slot machines, computer games, scientific research, as well as other cultural industries, which currently create a significant share of financial resources in the United States. A significant part of the country's population is employed in them. In connection with the development of the creative sector, in essence, a new social class is being formed the creative one.

Richard Florida in the bestselling book "Creative Class: People Who Change the Future" (Florida, 2002; Florida, 2005) singled out a new class of workers engaged in the field of creative economics - the creative. We are talking about people involved in advertising, architecture, various fields of art - art craft, design, fashion, cinema, music, theatre, literature and publishing, research, software development, new types of toys and computer games, as well as radio and television.

As the authors (Florida, 2002; Howkins, 2001) note and confirm the results of the other studies mentioned above, the importance of creative industries in the economies of developed countries are growing steadily, and together with them their contribution to the total growth of gross domestic product (GDP) is growing. Creative industries currently 
account for $7 \%$ of global GDP. The annual economic growth in OECD countries ranges from 5 to $20 \%$. As can be seen from the results of studies commissioned by the European Commission in 2006, the contribution of the creative sector of the economy to the GDP of EU countries in 2003 was $2.6 \%$. For comparison: real estate - 2.1\%, food, beverages and tobacco $-2.1 \%$, chemical and rubber industries, including plastic products $-2.3 \%$. In 1999-2003 The growth rate of the Quaternary sector was more than $12 \%$ faster than the average annual growth rate of the EU economy (European Commission. 2006).

The development of a creative economy will seriously affect the future economic growth of the developed countries of the world. A prerequisite for the further development of this sector of the economy is the presence of a certain level of economic knowledge, and above all, the development of a person's creative abilities, as well as the formation and development of a creative class. The conditions necessary for the development of a creative economy are far from identical in individual geographical regions. Since higher rates of development and certain economic benefits are associated with the creative economy, the question arises: will the differences between highly developed economies, regions and countries with lower development levels deepen due to the development of the creative economy.

Until recently, it was talked about the economy as a knowledge economy, an information economy, today it is a creative economy that uses the achievements of the knowledge economy and is based primarily on the materialization of new ideas and ideas.

The creative economy is the economy of the creative sector, which mainly relates to processes occurring in the service sector, but the results of activities in this area can be found in almost all areas of the economy. It relies on the high proportion of the creative class, which is considered the engine of innovation and new approaches both in the field of research and in the field of business, art, culture or design. One of the first to address the topic of creative economics in their works was J. Hawkins (9) and R. Florida (7). They drew attention to the contribution to the development of the economy of scientists, artists, talented people with creative thinking and the ability to generate original, unconventional ideas. They create the highest added value in developed economies. The characteristics of the creative and cultural industry and its impact on the growth of the national economy can be found in the latest publications of the famous economist J. Potts.

Economic growth depends on talented people who form the creative class. In his works, R. Florida draws attention to the fact that the number and, of course, the need for creatively thinking personalities increases in proportion to the growth of investment in scientific research. Since the early 1950s, there has been a constant increase in investment in the development of creative activity through research and development. Since 1953, the volume of these investments has increased from $\$ 5$ to more than $\$ 250$ trillion in this area in 2000 . The result of an increase in investment in research and development was an annual increase in the number of patents granted. The development of a creative economy is associated with the development of creative skills, an increase in the number of creatively minded workers, and with an increase in the number of firms in creative industries. The income level of representatives of the creative class and companies included in the creative sector far exceeds the average national level. Supporting the development of an innovative and creative sector is one of the most important steps in improving the competitiveness of economies. On this basis, there is an urgent need to assess the potential of the creative sector, its capabilities and the consequences that its development brings.

Currently, there are a number of works that consider the influence of accumulated human potential as one of the determining factors of economic growth (Bassanini and Scarpetta, 2001; Burniaux et al., 2006).

Most of these works are based on R. Solow's neoclassical model of economic growth (Solow, 1956). It has been widely used as a theoretical basis for explaining deviations of economic development indicators of various countries and based on elementary production functions. The significance of human capital is reflected in a two-sector version of the growth model, called the Uzawa - Lucas model (Lucas \& Robert, 1988). This model reflects the effect of the accumulation of material and human capital on per capita income. A variant of the growth model is the neoclassical model of exogenous growth by Mankiw et al., (1992), where the result is such functions of human and material capital as human labor (people of productive age) and the level of technology development.

However, all these theories are still based on the idea of limited resources. Here, while there is a search for new forms of resources. Of course, each model should be abstract, it should be a simplified reflection of reality and be based on the most significant factors. If a random phenomenon occurs that does not directly affect economic growth, there is no need to adjust old approaches and theories.

However, we believe that this is not a random phenomenon, but a phenomenon whose value will constantly grow. 
Ideas that can double production, creativity and technological progress open up new possibilities not only for rearrangement of existing sources. Thanks to technological progress, ideas occupy an increasing place in the structure of capital, and this phenomenon tends to develop. Man's unlimited creative thinking opens up amazing opportunities. This statement has far-reaching implications. The economies based on intellectual capital will develop faster, and the pace of their future growth and development is still impossible to imagine. And vice versa: economies whose attention will be focused on the development of other areas, and not on building a creative economy, will gradually decline.

Throughout history, many negative effects related to human life or life on our planet can be traced back to the design period (Ivanova, 2010). In this situation, the interaction of design with the creative economy in a nation is obvious and undeniable. Thus, the design is an activity aimed at creating the world with the involvement of material resources. Design which defines and shapes people's lifestyles is one aspect of the problems that people face (Wilde, 2020). The analysis shows that when firms invest in design, they are more likely to innovate, which will lead to higher productivity (Benton et al., 2018).

It is universally accepted that design is generally used to stimulate business growth in a wider economy, while it is highly utilized in creative fields (Design Council 2017). The designer thinks about the importance of applying sustainability in all areas of design and architecture (Sophie Thomas 2017).

It can be stated that there is the continuous and sustainable development of new inventions, new methods and new structures throughout history. When there is a serious change in technology, the economy, or people's daily lives, new ways and new types of action are needed (Whitney, 2015).

Acquaintance with the sciences of sustainable development, environmental humanities, economics, environmental policy and management allows researchers to better respond to global challenges. (Maher et al.,2018).

Designers must be read to interact with the situational understanding that is valuable to different participants from various perspectives (Van't Hoff et al., 2017). Today, many designers are still involved in the creation of complex things (Ravi, and Robert, 2014). Design shapes the world we live in. Comprehensive design research, especially if it is possible to approach them from intersecting perspectives, can uniquely combine theory, practice, and creativity. The great task of changing people's lifestyles within our planetary and social boundaries requires an answer.

As nations with developed economies adopt new technologies and business models, the demand for design skills and knowledge rises and grows rapidly (Council, 2018).

Getting a complete picture of the context of the selective economy will not only allow organizations to offer better options that no longer involve unnecessary or excess production but will also help us to choose the world we want to live in (Whitney, 2015).

The most interesting characteristic of the design is that it can be interpreted differently, and therefore it is impossible to give it an exact definition. But one thing can be clearly stated: It does not matter whether the design is created for pleasure that people admire about a product or established for a potential end-user, it is always created for a particular purpose (WORTH Partnership Project 2020).

\section{Materials and Methods}

According to the chosen idea, design is initially understood as a large single tool that helps to create a holistic competitive image of the product. Industrial design can help you figure out how much the economy has on the demand market, and later on design. The most common area in design is industrial design, each person in the house has industrial design items (Zolotoe, 2014). At the moment, entrepreneurs need to invest time and money in the design of their product. Huge amounts of money are invested in design in our country, and gradually it becomes more and more popular. Currently, many design studios are developing, doing research, studying new technologies, so the quality of their work is growing (Sukharev, 2015). Product packaging is becoming one of the leading and most sought-after services in the field of design. There are several types of product evaluation - quantitative characteristics: cost, power, dimensions, speed, as well as qualitative characteristics: ergonomics, style, convenience and comfort (Nelson, 1971).

In our country, design is developing and becoming competitive, as well as in advanced developed countries. The government of a developed country should support entrepreneurs so that their products benefit the country's economy. The economic growth of a country depends on how much the state helps ensure a dynamic and structurally balanced growth of companies. Also, the development of design will affect the standard of living of the population. Azerbaijan is a developing country, and our design will soon become at the European level, our country has every chance to 
develop the economy to the forefront (Zaykova, 2016).

Design is responsible for the aesthetic appearance of the product, for its functionality, and accordingly, design is directly related to the quality and ergonomics of the product; to the materials of which the product is made; to the development and idea through which a new product is being designed; the brand with which it becomes popularized and recognizable on store shelves; as well as to public relations formed between residents of the city and the country at the time of development and production of the product and its promotion to the consumer (Melnikov, 2000). Therefore, design is the most important innovative component of the process of developing, manufacturing and promoting a product. Design is a qualified service sector provided during the development of ideas and projects of companies in order to improve the functionality and aesthetic side of the product, which allows satisfying both the buyer and the manufacturer.

Having studied the role of design in the economy, we can say that design and the economy are closely related, as well as that design directly affects the economy of a company, city, country (Tjalve, 1984). Design cannot but have an economic part, for the development of design is based on the production of a new and most effective sale of goods on the market. The main role in the promotion and marketing of goods is played by the economy. Having studied the economy, we can determine whether the company is growing or dying away. Design helps identify the target audience and ideal customer for each product. The economy shows what demand for this product (Sukharev, 2015).

\section{Results and Discussion}

Currently, the world economy is at the stage of the next cycle of a big boom. According to the results of authoritative research and expert assessments, the peak point of this cycle will be between 2030-2040 (Lebedeva, 2013).

Designers in the modern world are required everywhere. Neither industrial giant enterprises, nor small firms that produce goods for every day can do without them. Designers develop product packaging, think over the exterior and interior of buildings and cars, and contribute to the concept of urban development. Whereas in the West, designers actively collaborate with the state in return for its support, then in Russia, design communities are only beginning to master the work on a large scale. First of all, we will understand what design is and what it happen.

There are many design definitions. According to one of them, "design" is a type of artistic activity for the development of industrial products with high consumer, aesthetic, functional and technological properties, as well as an activity that organizes the subject environment of his life that is comfortable for a person. The design is based on consumer, technological and aesthetic functions. Modern design is a special area of use of art and design thought, where it is very difficult to separate color from form, to distinguish planar graphics from volumetric, constructive construction from sculptural plastic, an object from the environment, and the like. All of the above is a variety of forms of manifestation of design, which allows design to focus on solving large-scale problems related to the creation of an artificial human environment at all its stages - from saturating the private interior with objects to projects for the formation of a metropolis or even to working out global ethno-cultural and social political communities (Nassbaum, 1997).

The design development concept in Azerbaijan refers to the professional activity of the designer, which develops on a social basis, and at the same time, relies on the natural qualities of a person, which include aesthetic, emotional and intellectual. This concept determined the role and place of design in society. The purpose of design at this stage is to increase the aesthetic activity of society, to exalt the personality, adding self-esteem and dignity to it. Design characterizes a company that makes it recognizable.

Industrial design includes the whole range of possible design objects: goods necessary for everyone; advertising, all types of interiors, equipment and transport, military and space technical support, environmental and industrial facilities, and even social facilities. The leaders in industrial design today are Japan, Holland and France (Industrial aesthetics of the United States, 1967).

The attitude of the state to the design market in foreign countries is very different from the Azerbaijanone. Large companies in France, realizing the benefits of working with designers, set up their own design bureaus. The most famous company among them is Renault, whose design activities are carried out by about 250 specialists. But French small and medium-sized enterprises still rarely use the services of designers. Therefore, the French government pursues a policy of introducing design in such enterprises, with the aim of successfully competing with manufacturers in other countries. Two important departments are responsible for promoting design in France - the Ministry of Culture and the Ministry of Industry. They finance research, support designers and enterprises, develop art educational institutions, and also provide grants for the publication of publications on design. The country has established regional directorates of industrial and environmental research and industrial design centers (Glazyev \& 
Fetisov, 2013).

Good design can take to a new level not only one particular company or a separate city, but also the whole country. An example of this phenomenon is China. Design technologies are actively developed and applied in the country. A huge incentive to the development of design was the appearance in China of international business and, following this, the modernization of the country's economy. The government began to support industrial design at the national level, which includes financial investments in research projects, educational development, interaction with sales agents, international contacts aimed at promoting design. The result of all these actions was a significant increase in the level of design of Chinese goods, which is characterized by the creation of a national school of design, the use of a national design language (Antonova, 2011).

Nowadays, domestic designers are a bit behind foreign ones. But some of our specialists and design communities can compete with Europeans and Chinese. Today, Azerbaijani designers are guided more by the local consumer - the development of corporate identity, packaging of goods, advertising, design of exhibition stands, and television remains a priority. However, our design companies have already made a small breakthrough, began to interact with foreign customers and collaborate with foreign colleagues, exchanging experiences. Several large companies are known abroad and even have representative offices there.

In the global economy, design is considered the main strategic moment in production. This is due to the fact that crises in the 2000s led to the need to update the economic model and big changes in almost all areas of human life. And while most developed countries have managed to find a way out of this situation, in Russia there is a problem of bringing design to the level that would allow meeting real consumer needs.

There are much more new technologies in production than changes in product design and business strategies of supplying companies (Glazyev, 2015). It can be concluded that innovation in the economy is a necessary solution for the present. The following problems are of acute social character: lack of resources, accessibility problem, security problem, state of ecology. Innovative ideas are not accepted immediately. They require careful preparation, analysis, a reasonable introduction to the masses, and conveying to consumers their benefits.

In order for designers to work at a modern competitive level, it is necessary that all the developments envisaged in the theoretical and methodological direction turn into the knowledge and skills of practicing designers. We believe that it will be necessary to introduce adjustments to educational standards, write the appropriate teaching aids and train teachers. To increase the demand for design, it is necessary to develop and put into practice methods and means of creating an interest for managers of all levels, entrepreneurs, engineers and managers in using design to create or upgrade all types of products, structures and systems.

As mentioned earlier, new growth theories will be forced to take into account this new phenomenon of creativity, since the development of a creative economy involves the use of both limited and unlimited resources.

The development of a creative economy is associated with certain conditions. The requirements that must be observed for the development of the creative sector can be classified into three main areas. They determine what is most essential for a society that sees an instrument of economic growth in the development of a creative economy. We are talking about consumers, labor resources and space (microclimate). A prerequisite for the growth of the contribution of the creative sector of the economy to the production of GDP is the level of intelligence and financial security of consumers, the ability and level of professional training of the workforce, as well as a highly developed economic and technological space that is open to new original solutions and has a developed institutional base. The space in which the creative sector is developing dynamically is characterized by a high level of economic development, when the majority of the population does not have problems in meeting their basic needs, and an excess of financial resources is spent on purchasing products from the creative sector (attending concerts, cinema, theater, purchasing items art, interior, etc.).

If we take into account a rather long retrospective, then modern economically developed countries have achieved their success on the basis of economic growth that has lasted for many decades. At the same time, long-term economic growth offers the prospect of becoming an economically developed country for current developing countries. South Korea has already made such a path, China is confidently following it (Zadresenets, 2009). That is why, in our opinion, it is legitimate to assert that economic growth forms the basis of economic development.

According to the above factors, we can formulate the following factors for the development of the economy. 


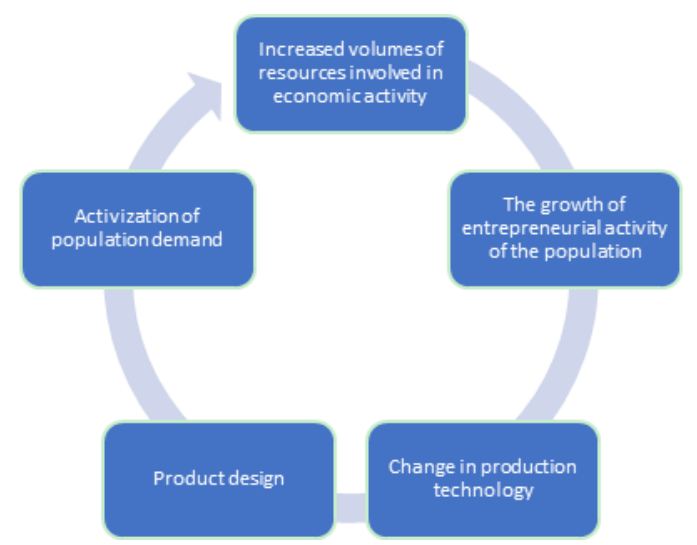

Figure 1. Factors of economic development of the country

We can safely say that design as a factor in the development of the country's economy occupies an important niche, and can be considered as an element of the overall system.

The essence of the national economy lies in the fact that it is an established system of national and social reproduction of the state, in which sectors, types and forms of social labor are interconnected, resulting from the long historical evolutionary development of a particular country. The influence on the characteristics of the national economy is exerted by historical, cultural traditions, the geographical position of the state, its role in the international division of labor, etc.

Within the framework of the national economy, the influence of economic growth factors is complexly interconnected. The main task of the state is to make full use of existing economic factors, redirect them in the right direction in order to orient economic growth to the realization of the interests of the entire population.

In a modern market economy, along with marketing research, design and advertising research is becoming more widespread. Design studies play a particularly important role in the largest design firms in the world.

“... Nowadays," writes Bruce Nassbaum in BisinessWeek magazine, "the approach to product design is directly linked to the technical capabilities of serial production and market research in order to ensure maximum sales." This formula contains the main meaning of the development of the modern market. Only an integrated approach that takes into account the contribution of all participants in the market process (marketing - production - information marketing) can ensure the normal functioning of the market mechanism.

It is known that one of the main tasks of the design of industrial products is to solve the problems of their shape. But you must never forget that any product has an internal and external shape. The internal form, as a rule, determines the convenience of assembly, operation and other utilitarian properties of the product, and the external form determines its aesthetic and socially significant properties (Melnikov, 1984).

"Americans are very fond of all kinds of changes and therefore put significant pressure on the industry, demanding improvements in both the performance of the products and their appearance. The manufacturer knows that he must meet the consumer - otherwise his competitors will oust him," it was written in the prospectus, which was issued to every visitor at the first Moscow exhibition "Industrial Aesthetics of the USA" in 1969" (Tjalve, 1984).

The complexity of the form affects the amount of material and physical labor required for the manufacture of the product, which in turn determines the necessary production costs and the cost of the finished product. From this it becomes clear how important it is for an entrepreneur to understand the optimality of making design decisions both from a purely technical and economic point of view before the products intended for release take their place in the competitive environment of a particular market segment. It is easy to see that the model takes into account advertising costs, which is currently a "sore spot" for many Russian enterprises (especially those who produce conversion, high-tech and high-tech products). All this together determines the necessary level of financing and investment in the production (primarily in technology) of the required funds (Koshelev National economy.").

As follows from the model, the nature of the form can be determined by a variety of requirements, i.e. this is a multi-factor product characteristic that depends on almost all market parameters (starting from the design and technological features of the product and the price of the material, ending with the national traditions and "quirks" of the client). 
There are many definitions, both design and advertising. But those who think that only recently have they started talking about product design and advertising are mistaken. Let's try to answer the following questions: "How to organize a design process that takes into account all these factors? Where is the "battery" that, having absorbed all the information, would be able to use it and purposefully send it to the right direction ?. Who will it be - a designer, technologist, economist, ergonomist or someone else?"

The concept of "art" at that time covered all knowledge and arts that were of an applied nature: technology (in particular, mechanics), architecture, sculpture (sculpture), painting, engraving, etc. At the time, various crafts belonged to the lower ranks of the same art. No wonder the design is called "industrial art", investing in this concept its generalizing meaning. Art is the ability to think collectively, to combine available facts into a single whole and on their basis to create an energetically concentrated image of a very concrete work. But industrial art implies that this work should have, first of all, market value, which means that it will be mass-produced or even mass produced under specific production conditions, after which it must find its mass buyer. What difficulties does the designer face in the implementation of the task assigned to him?

In order to want to do something, you need to clearly understand how to do it. And this, in addition to the desire of the designer, is determined by the technical level of preparation of the company, i.e. what equipment, equipment and tools the company currently possesses and what can be done with this equipment. Possessing such information, knowing the needs of the market, the designer, possessing, in addition, enhanced creative abilities, is called upon, in order to achieve the market goals of the company, to combine everything into a master project.

"The design solution for any product is, in a sense, social communication," writes George Nelson. - And the point is not so much in the importance of the object (this is usually not subject to the control of the designer), but in the passion invested in the study and expression of the essence. The most important design property of a product of any size is the veracity of its internal essence, and people usually understand this. ... The designer's duty is to develop an artistic vision of the modern world. By this I mean a holistic vision, including the views of a scientist, mathematician, and any creative worker in general" (Sukharev, 2015).

In countries with developed market economies, it has long been concluded that such a person should be a designer. Remember who made the "revolution" in the American automotive industry in the 80s. These were Ford Jack Jack Telnak and Ray Evers, who created the world's first Tourus aerodynamic body model. Jack Telnak, being vice president of the design firm, managed to unite everyone around his idea - from a designer to a simple worker. But in fairness it must be said that this discovery does not belong to them.

The prototype of a designer with such coordinating functions can be found in the outstanding Russian mechanical engineer A.K., developed back in 1724. Sled project of the Academy of Arts.

Peter Bressler, one of America's most versatile and respected industrial designers, says industrial design is an essential link between consumer needs and technology. The designer imagines what the consumer wants from the point of view of sales and design search, in the forms that will receive an engineering embodiment. The designer is called upon to create such images that help the consumer to perceive, understand and feel the technical aspect of the design.

At the congress of ICSID (the International Council of Design Organizations, established in 1957), in September 1969 , the following design definition was adopted: "DESIGN is understood as creative activity, the purpose of which is to determine the formal qualities of objects produced by industry".

Currently, the main feature of design is the convenience of products. A convenient thing that creates comfortable conditions for a person is always distinguished by aesthetic expressiveness, i.e. a sign of beauty. Famous aircraft designer O.K. Antonov said that the artist often painted the shape of the planes for him, and he took it as a basis, because she, as a rule, turned out to be the best. Why? Yes, because a beautiful thing is rational. Design is of great importance not only in technology, because it embodies the technical feasibility born of the creative energy of the creator of this product, but in the vast majority of cases it is the main factor determining the decision of the consumer to purchase a particular product.

What is all this talking about? Without the creative energy invested by the creator in a particular product, a competitive product cannot be born. The creative process requires processing, rethinking the existing heritage, including the heritage of competitors. It is known that a person cannot even imagine what he does not know. And everything new is the development of what has already been accumulated by mankind and concentrated in the information arrays of special, technical, scientific, artistic, graphic and other literature, as well as accumulated in the memory of every person, including at the genetic level. That is, the creative energy of the predecessors is accepted by 
the followers and converted into their own creative energy. For example, Picasso's cubism is based on a seemingly primitive African sculpture with multifaceted surfaces, which struck him when he visited the Ethnography Museum. "I'm bewitched," he said, and began to cut the same idols. As a result, a new direction in world art arose.

And one of the founders of the design, the German scientist and practitioner Walter Gropius, back in 1913 noted: "A thing that is technically remarkable must be imbued with a spiritual idea, be formalized, so that it will be guaranteed an advantage among many such products." And he immediately emphasized that "the style of the product chosen by the designer can always be justified and with the help of advertising spread around the world." If industrialists aim their ADVERTISEMENT on creating the most favorable image with the most sharply defined individuality for their goods, then, in the long run, they will receive the most part of the market and the greatest profits.

Numerous quotes and definitions can be given from a wide variety of sources. But the main thing that unites them is a creative beginning. Both the design of industrial products and advertising are the product of a person's creative activity, that is, it is, first of all, the category of transfer of creative energy from the creator or creators of the product to its consumer, and therefore design is a factor in the development of the country's economy.

\section{Conclusion}

The development of a creative economy is based on a new phenomenon - on unlimited resources of economic growth, on a person's ability to create. Creativity, manifested in the generation of new ideas amenable to implementation and subsequent commercialization, can expand production without attracting additional labor and capital. This phenomenon contributes to the growth of value added and is the main engine of economic development in developed economies. It is based on the premise of unlimited creative resources, intellectual and creative capital. Mastering these resources can lead to large-scale changes, and not only in economic theory based on the law of limited resources and factors of production.

Our study showed that design as a factor in the development of the economy in the modern trends of globalization has tremendous power, is indispensable and, moreover, fundamental. Moreover, this aspect of the economy, namely the development of the country's economy, needs further research.

1. Above all, recognize that the creative economy generates not only economic benefits but also non-monetary value, which makes an important contribution to the inclusive and sustainable development of society.

2. Promote culture to become the driving force of economic, social and environmental development processes, because positive changes can only take place in a society defined by culture.

3. Identify opportunities by mapping local assets of the creative economy. This analysis will be the basis for the improvement of further action plans in this sector.

4. Build up the evidence base through careful collection of data as a fundamental investment in any consequent policy of the development of the creative economy in the region.

5. The nexus between the formal and informal sectors of the creative economy plays a crucial role in developing adequate policy, the reason is that in developing countries the creative economy is largely based on informal cultural systems, processes and institutions and it is excluded from the public sector and family and friends become the main investors of creative entrepreneurs.

6. Investigate the critical success factors that help to pave new methods of developing local creative economy. These factors of success include the availability of infrastructure and labour resources, availability of legislation protecting intellectual property rights, access to global markets, etc.

7. Invest in the sustainable creative development of enterprises along the value chain. This means that it is vital to support local training and innovation because without them there can be no new talents or new creative firms.

8. Establish new opportunities for cultural entrepreneurs in the field of business administration and social networks, involving them in marketing activities and providing urban areas suitable for the development of the social and cultural structure of the society.

9. Engage in international cooperation to promote productive mutual learning, as well as the exchange of information and experience.

10. Adding culture factor into the local economic and social development programs and it should be considered as an important factor while facing competitive priorities.

The implementation of the Concept of Sustainable Development is generally accepted as a key task of public policy in the 21st century (Malik, 2011; Helne and Hirvilammi, 2015). In this situation, creative or innovative, design 
activity is one of the important conditions for the long term and sustainable development (Villajos et al., 2019). Despite the development of science and technology and the improvement of aesthetics, there is an endless need for the use of aesthetic objects in human civilization. The perception of objects by human senses, the possibility of relying on automated technology and the complexity of the environment is increasing day by day. In terms of responding to human desires, the design will permanently stay at a certain level of research and development of materials to meet needs.

Therefore, the current issues of innovative design always attract attention. It can be assumed that thanks to the development of science and technology and practical problems arising from hasty design and production, sustainable design must be properly understood (Lilley, 2009; Ayres and Kneese, 1969). In addition to this, issues related to reducing environmental impacts were directed to sustainable design and sustainable consumer behaviour (Tang and Bhamra, 2012; De Medeiros et al., 2018). However, aesthetic and practical design is still a difficult task for designers (Tromp et al., 2011, Belz and Peattie, 2009).

\section{References}

Aliyev, A. I. (2006). Speech of the President of the Republic of Azerbaijan I. Aliyev at the business forum Azerbaijan - United Arab Emirates in Abu Dhabi (pp. 104-105). Dirchialish - XX1 Yasr.

Antonova, Z. G. (2011). Modernization of the economy as a major factor in economic growth. News of Tomsk Polytechnic University, 6, 10-15.

Ayres, R. U., \& Kneese, A. V. (1969). Production, consumption, and externalities. The American Economic Review, 59(3), 282-297.

Bassanini, A., \& Scarpetta, S. (2001). Does human capital matter for growth in OECD countries? Evidence from pooled mean-group estimates. OECD Economics Letters, 74, 399-405. https://doi.org/10.1016/S0165-1765(01)00569-9

Belz, F. M., \& Peattie, K. (2009). Sustainability marketing. Glasgow, Hoboken: Wiley \& Sons.

Benton, S., Miller, S., \& Reid, S. (2018). The Design Economy 2018-The state of design in the UK. London, UK: Design Council. Retrieved October 15, 2018, from https://www.designcouncil.org.uk/sites/default/files/asset/document/Design_Economy_2018_exec_summary.pdf

Burniaux, J. M., Padrini, F., \& Brandt, N. (2006). Labour market performance, income inequality and poverty in OECD countries. OECD Economics Department Working Papers, No. 500. OECD Publishing (NJ1). Retrieved from https://eric.ed.gov/?id=ED504024

Council, D. (2017). Designing a Future Economy: Developing design skills for productivity and innovation. Retrieved from https://www.designcouncil.org.uk/what-we-do/research/designing-future-economy

Council, D. (2018). The design economy 2018: The state of design in the UK. London, UK: Design Council.

Council, D. (2018). The Design Economy 2018: The state of design in the UK. Retrieved October 15, 2018, from https://www.designcouncil.org.uk/sites/default/files/asset/document/Design_Economy_2018_exec_summary.pdf

European Commission. (2006). The economy of culture in Europe. Retrieved from http://ec.europa.eu/culture/key-documents/doc873_en.htm\#bad_nodepdf_word/economy_cult/executive_summ ary.pdf

Florida, R. (2004). The rise of the creative class and how it's transforming work, leisure, community and everyday life (Paperback Ed.). GEN, New York: Basic Books. Retrieved from https://olin.tind.io/record/135543

Florida, R. (2005). Creative class: people who change the future. M., Izdatelsky dom Klassika-XXI.

Glazyev, S. Yu. (2015). On urgent measures to strengthen the economic security of Russia and bring the Russian economy to the path of accelerated development. Moscow, Ies Ran, 196(7), 86-186. Retrieved from https://neuromir.tv/media/1981/doklad-glazyeva-s-yu-_o-merakh-ek-bezopasnosti.pdf

Glazyev, S. Yu., \& Fetisov, G. G. (2013). On the strategy of sustainable development of the Russian economy. Ekonomicheskiye I Sotsial'nyye Peremeny: Fakty, Tendentsii, Prognoz, 1, 23-25.

Helne, T., \& Hirvilammi, T. (2015). Wellbeing and sustainability: A relational approach. Sustainable Development, 23(3), 167-175.

Howkins, J. (2002). The creative economy: How people make money from ideas. Penguin UK. 
Industrial aesthetics of the United States. (1967). Catalog of the international exhibition, Moscow (p. 64).

Ivanova, M. (2010). UNEP in global environmental governance: design, leadership, location. Global Environmental Politics, 10(1), 30-59. Retrieved from https://www.mitpressjournals.org/doi/pdf/10.1162/glep.2010.10.1.30

Kislitsina, E. A. (2015). The influence of design on the economic condition of the country and vice versa. Electronic Periodical Scientific Journal Sci-Article.Ru. Retrieved from http://sci-article.ru/stat.php?i=1449836839

Koshelev, A. N. (2008). National economy. Retrieved from https://econ.wikireading.ru/32379

Kuliev, R. A. (2007). Transitional economy of Azerbaijan: some aspects of development (p. 240).

Lebedeva, V. D. (2013). The influence of factors on economic growth and state development. Proceedings from II International Scientific Conference: Problems and Prospects of Economics and Management (pp. 22-24). St. Petersburg, Renome.

Lilley, D. (2009). Design for sustainable behaviour: strategies and perceptions. Design Studies, 30(6), 704-720.

Lucas, R. E., \& Robert, L. (1988). On the mechanics of economic development. Journal of Monetary Economics, 22(1), 3-42. Retrieved from https://www.sciencedirect.com/science/article/abs/pii/0304393288901687

Maeda, D. (2008). Laws of simplicity: Design. Technology Business A life. Moscow, Al Pina Business Books. Retrieved from https://designopendata.files.wordpress.com/2014/05/lawsofsimplicity_johnmaeda.pdf

Maher, R., Maher, M., Mann, S., \& McAlpine, C. A. (2018). Integrating design thinking with sustainability science: a Research through Design approach. Sustainability Science, 13(6), 1565-1587. Retrieved from https://link.springer.com/article/10.1007/s11625-018-0618-6

Malik, K. (2011). Evaluation of regional development policy: methods, contexts and dimensions of sustainable development. Studia KPZK, 135.

Mankiw, N. G., Romer, D., \& Weil, D. N. (1992). A contribution to the empirics of economic growth. The Quarterly Journal of Economics, 107(2), 407-437. $\quad$ Retrieved from https://eml.berkeley.edu/ dromer/papers/MRW_QJE1992.pdf

Medeiros, J. F., Da Rocha, C. G., \& Ribeiro, J. L. D. (2018). Design for sustainable behaviour (DfSB): Analysis of existing frameworks of behavior change strategies, experts' assessment and proposal for a decision support diagram. Journal of Cleaner Production, 188, 402-415.

Melnikov, O. N. (2000). Place of design and advertising in business. Russian Business, 3, 103-111.

Muzaffarli, N. (2014). Social orientation of the economy in the rightist and leftist systems of Baku. Baku, Shatg-Garb.

Nassbaum, B. (1997). Winners. The best design developments of the year. Business Week, 1, 45.

Nelson, J. (1971). Problems Design / Per. from English. D. Nelson. - Moscow: Art.

Nixson, F. I. (2001). Development economics. Heinemann.

Ravi, C., \& Robert, F. (2014). Internet Design for Emerging Markets Innovations: Technology, Governance. Globalization, $9(3-4), \quad 113-121 . \quad$ Retrieved $\quad$ from https://www.mitpressjournals.org/doi/pdf/10.1162/inov_a_00222

Solow, R. M. (1956). A contribution to the theory of economic growth. The Quarterly Journal of Economics, 70(1), 65-94. Retrieved from http://piketty.pse.ens.fr/files/Solow1956.pdf

Sukharev, O. S. (2015). Institutional factors and a macro model of economic growth. Investments in Russia, 11, 28-35.

Sukharev, O. S. (2015). The industrialization strategy and import substitution: initial conditions and opportunities. Investments in Russia, (10), 24-33.

Tang, T., \& Bhamra, T. (2012). Putting consumers first in design for sustainable behaviour: a case study of reducing environmental impacts of cold appliance use. International Journal of Sustainable Engineering, 5(4), 288-303.

Thomas, S. (2017). Why is design so important for the economy?. Retrieved December 6, 2017, from https://www.jumpthegap.net/blog/Why-is-design-so-important-for-the-economy

Tjalve, E. (1984). Short course in industrial design. Moscow, Mashinostroenie.

Tromp, N., Hekkert, P., \& Verbeek, P. P. (2011). Design for socially responsible behavior: a classification of 
influence based on intended user experience. Design Issues, 27(3), 3-19.

Van 't Hoff, M., Wall, R., Willigen, J., \& Rand, L. (2017). Design factors for economic development: spatial design in the metropolitan area as a factor of economic competitiveness. https://doi.org/10.13140/RG.2.2.26933.7344

Villajos, E., Tordera, N., \& Peiró, J. M. (2019). Human resource practices, eudaimonic well-being, and creative performance: the mediating role of idiosyncratic deals for sustainable human resource management. Sustainability, 11, 6933.

Whitney, P. (2015). Design and the Economy of Choice. She Ji: The Journal of Design, Economics, and Innovation, 1(1), 58-80. Retrieved from https://reader.elsevier.com/reader/sd/pii/S2405872615300319?token=FE28B7773496923607EE4E74F97F20C2 9FC3DA3D86E40735C58DE8BADABEFBE942032A62362908FC82A1C6734B201F65

Wilde, D. (2020). Design research education and global concerns. She Ji: The Journal of Design, Economics, and Innovation, 6(2), 170-212.

Worth Partnership Project. (n.d.). The impact of design on the economy.

Zadresenets, E. E., \& Sergeeva, G. K. (2009). Design - technologies for creating and promoting innovative products in the consumer market. Moscow, Vniite, 1(2), 15-19.

Zaykova, I. A. (2016). Economic growth as the basis of economic development. Natsionalnyye Interesy: Prioritety I Bezopasnost, 9(342), 51-60,

Zolotoe, A. V. (2014). On the valuable experience of economic development. Bulletin of the Nizhny Novgorod University. N. I. Lobachevsky, 2(1), 262-263. Retrieved from https://cyberleninka.ru/article/n/o-tsennom-opyte-ekonomicheskogo-razvitiya

\section{Notes}

Note 1. This is an example.

Note 2. This is an example for note 2.

\section{Copyrights}

Copyright for this article is retained by the author(s), with first publication rights granted to the journal.

This is an open-access article distributed under the terms and conditions of the Creative Commons Attribution license (http://creativecommons.org/licenses/by/4.0/). 